\title{
Assessment of Pollution Levels of Suspended Particulate Matter on an Hourly and a Daily Time Scale in West African Cities: Case Study of Ouagadougou (Burkina Faso)
}

\author{
Issoufou Ouarma1, Bernard Nana ${ }^{1,2}$, Kayaba Haro ${ }^{1,3}$, Antoine Béré1* Jean Koulidiati1 \\ ${ }^{1}$ Laboratoire de Physique et de Chimie de l'Environnement (LPCE), Université Joseph KI-ZERBO, Ouagadougou, Burkina Faso \\ ${ }^{2}$ Institut Des Sciences (IDS), Ouagadougou, Burkina Faso \\ ${ }^{3}$ Institut de Recherche en Sciences Appliquées et Technologie (IRSAT), Centre National de la Recherche Scientifique et \\ Technologique (CNRST), Ouagadougou, Burkina Faso \\ Email: *berebiya@yahoo.fr
}

How to cite this paper: Ouarma, I., Nana, B., Haro, K., Béré, A., \& Koulidiati, J. (2020). Assessment of Pollution Levels of Suspended Particulate Matter on an Hourly and a Daily Time Scale in West African Cities: Case Study of Ouagadougou (Burkina Faso). Journal of Geoscience and Environment Protection, 8 , 119-138. https://doi.org/10.4236/gep.2020.811007

Received: September 16, 2020 Accepted: November 13, 2020 Published: November 16, 2020

Copyright () 2020 by author(s) and Scientific Research Publishing Inc. This work is licensed under the Creative Commons Attribution International License (CC BY 4.0).

http://creativecommons.org/licenses/by/4.0/

\begin{abstract}
In Western countries, research works on air quality have reinforced in recent years because of the links between the level of particulate pollution in numerous cities and the appearing of various health disorders including cardio-respiratory pathologies, acute bronchopneumonia, lung cancer, etc. In sub-Saharan Africa countries, particularly Burkina Faso, there is very few similar research. In the present work, the pollution levels of airborne particle in the city of Ouagadougou have been assessed through two campaigns of in situ measurements of suspended particulate matter concentrations. These measurements which have concerned $\mathrm{PM}_{1}, \mathrm{PM}_{2.5}$ and $\mathrm{PM}_{10}$ were performed using a portable device (AEROCET531S) at nine sites in 2018 and at ten sites in 2019. These sites are located on roadside, administrative services, secondary education establishments and outlying districts. The results show that: 1) the $\mathrm{PM}_{1}$ concentrations values presented no significant variation between days, seasons or sampling sites; 2) the 24-hour $\mathrm{PM}_{2.5}$ concentrations often exceeding WHO recommended concentrations and, 3) the 24-hour $\mathrm{PM}_{10}$ concentrations exceed WHO recommended concentrations regardless of the season or the sampling site. In indeed, the average 24-hour concentrations are $20 \pm 4,87 \pm 16$ and $951 \pm 266 \mu \mathrm{g} \cdot \mathrm{m}^{-3}$ for the $\mathrm{PM}_{1}, \mathrm{PM}_{2.5}$ and $\mathrm{PM}_{10}$, respectively. They are $17 \pm 3,29 \pm 5$ and $158 \pm 43 \mu \mathrm{g} \cdot \mathrm{m}^{-3}$, respectively, in 2018 dry season and, $12 \pm 1,22 \pm 9$ and $187 \pm 67 \mu \mathrm{g} \cdot \mathrm{m}^{-3}$, respectively, in 2019 rainy season.
\end{abstract}




\section{Keywords}

Urban Air Pollution, $\mathrm{PM}_{1}, \mathrm{PM}_{2.5}, \mathrm{PM}_{10}$, AEROCET, Ouagadougou

\section{Introduction}

Air pollution is a serious problem that affects the life of billions of people every year (Louati, Son, and Chabchoub, 2018); (Son and Louati, 2016). Africa has been singled out by UN HABITAT as the fastest urbanizing continent in the world (UN-HABITAT, 2010). This fact is accompanied by pollutions, particularly those of air by particulate matter (PM) emission that can cause multiple adverse long-term as well short-term effects on the human wellbeing such as increased health problems (Li et al., 2018) (Chen et al., 2019) (Cassee et al., 2013) (Beltrando, 2014) (Chang, Peng, and Dominici, 2011). In the same vein, and according to the World Health Organization (WHO), more than 25\% of deaths around the world may directly be linked to pollution.

By the aerodynamic diameter (Di), PM can be divided into nanoparticles or $\mathrm{PM}_{0.01}(\mathrm{Di}<0.01 \mu \mathrm{m})$, ultrafine particles or $\mathrm{PM}_{1}(\mathrm{Di}<0.1 \mu \mathrm{m})$, fine particles or $\mathrm{PM}_{2.5}(\mathrm{Di}<2.5 \mu \mathrm{m})$, and fine particles or $\mathrm{PM}_{10}(\mathrm{Di}<10 \mu \mathrm{m})$ (Duan et al., 2015). The composition and size distribution of particles depend on their formation processes, including their source that has been explored in numerous studies (Tsai et al., 2015).

According to Chatoutsidou and Lazaridis (Chatoutsidou and Lazaridis, 2019), PM may be classified into two groups based on their sources: 1) naturally originated PM and 2) anthropogenic originated PM. The first group includes PM that are emitted by natural sources such as sea spray, volcanoes, forests, and deserts. On the other hand, common anthropogenic sources are power plants, industries, aviation, vehicles, re-suspension, processes that utilize combustion (the use of biomass as domestic energy, common waste burning practices in residential areas). Previous studies showed that road dust emissions can increase $\mathrm{PM}_{10}$ by $21 \%-35 \%$ at traffic stations, $17 \%-34 \%$ at urban administrative sites, $17 \%-22 \%$ at industrial sites and 9\% - 22\% at rural sites (Amato et al., 2016).

Meteorological parameters such as temperature, humidity, wind speed and direction play a crucial role in air pollution mitigating (Radaideh, 2017) (Kliengchuay et al., 2018) (Janae et al., 2014). In normal weather conditions, the temperature decreases with altitude so that the pollutants emitted on the ground rise and disperse. This physical phenomenon fades as soon as there is a temperature inversion that favors an accumulation of pollutants in the air, especially in urban environment because at the ceiling of inversion, the pollutants will not be able to disperse any more (Sarr et al., 2018). This would result in containment of pollutants and an increase in concentration at the beginning of the night (Petäjä et al., 2016). Lindén and coauthors (Lindén, Thorsson, and Boman, 2012) have highlighted the relationship between atmospheric stability and pollutant levels in 
Ouagadougou's climate. It was pointed out that $\mathrm{PM}_{10}$ levels were substantially higher during unstable weather conditions compared to moderately stable atmospheric conditions across selected locations with various land cover, land use, and traffic density. A similar relationship in the morning is discussed by Etyemezian and coauthors (Etyemezian et al., 2005) which links the largest peak of air pollution to Addis Ababa to a higher atmospheric stability in the morning caused by temperature inversions at the surface during the night. The different intra-urban trends in PM concentrations between day and night can be explained by the difference between the sources of PM. Indeed, there is probably a greater influence of traffic dust suspension on paved and unpaved roads, the exhaust emissions in the morning to that adds the effect of using biomass as a source of energy as we move forward in the day. In addition to these sources, we can list the contribution of the dry season by the Harmattan of Sahara dust and local dust. More stable night conditions favor a mixture of suspended dust with particles generated by combustion and circulation, resulting in more uniform levels of $\mathrm{PM}_{2.5}$ in the evening.

Meteorological parameters of Ouagadougou are described in section 2.1. In general, wind speeds are low and stable and this is favorable for a stagnation of pollutants in the air, especially after 6:00 pm (Eliasson, Jonsson, and Holmer, 2009). However, the main origin of air pollutants and air pollution, is urban such as re-suspension related to traffic on paved and unpaved roads (Boman et al., 2009). Indeed, according to Boman and coauthors (Boman et al., 2009), most of the geological material found in $\mathrm{PM}_{10}$ is due to dust suspension from roads related to the prevalence of unpaved roads, the use of biomass as domestic energy and waste incineration. Some natural sources contribute also to PM such as the Saharan desert, which is the world's largest source of wind dust (Goudie and Middleton, 2001), the Bodélé's depression in Chad, which contributes to inject an important quantity of dust transported by Harmattan in the atmosphere of West Africa. A study of long-range dust transport shows that West Africa is the region the most affected by dust transported from the Saharan desert but the least studied (De Longueville et al., 2010).

Some studies on air pollution in the city of Ouagadougou show that this pollution is mainly due to PM and hydrocarbons (Eliasson, Jonsson, and Holmer, 2009) (Boman et al., 2009) (Nana et al., 2012) (Lindén et al., 2012). The PM concentrations exceed two or three times the recommended concentrations. Eliasson and coauthors (Eliasson, Jonsson, and Holmer, 2009) were assessed the $\mathrm{PM}_{10}$ concentrations to $578 \mu \mathrm{g} \cdot \mathrm{m}^{-3}$ in central business district, $1123 \mu \mathrm{g} \cdot \mathrm{m}^{-3}$ in high standing residential and $1884 \mu \mathrm{g} \cdot \mathrm{m}^{-3}$ in traditional residential. Nana and coauthors (Nana et al., 2012) have obtained $\mathrm{PM}_{10}$ concentrations of $135.8 \mu \mathrm{g} \cdot \mathrm{m}^{-3}$ in February 2007, $302.9 \mu \mathrm{g} \cdot \mathrm{m}^{-3}$ in March 2007, $116.5 \mu \mathrm{g} \cdot \mathrm{m}^{-3}$ in April 2007, 183 $\mu \mathrm{g} \cdot \mathrm{m}^{-3}$ in May 2007 and $92.9 \mu \mathrm{g} \cdot \mathrm{m}^{-3}$ in June 2007. Lindén and coauthors (Lindén et al., 2012) have measured $\mathrm{PM}_{10}$ concentrations to $162 \pm 144 \mu \mathrm{g} \cdot \mathrm{m}^{-3}$ and $69.0 \pm$ $46.6 \mu \mathrm{g} \cdot \mathrm{m}^{-3}$ for extreme and moderate pollution situations, respectively, in dry season 2007. These concentrations exceed the 24-hour $\mathrm{PM}_{10}$ concentrations 
recommended by the WHO and European Environment Agency (EEA) (50 $\mu \mathrm{g} \cdot \mathrm{m}^{-3}$ ), as well as United States Environmental Protection Agency US EPA (150 $\mu \mathrm{g} \cdot \mathrm{m}^{-3}$ ). However, these concentrations are lower than the 24 hours total suspended particles recommended limit of $200-300 \mu \mathrm{g} \cdot \mathrm{m}^{-3}$ by Burkina Faso authorities (Presidence du Faso, 2001). It will be noticed that there are no recommended limits especially for $\mathrm{PM}_{2.5}, \mathrm{PM}_{10}$ and other in Burkina Faso.

In this paper, we present an analysis of $\mathrm{PM}\left(\mathrm{PM}_{1}, \mathrm{PM}_{2.5}\right.$ and $\left.\mathrm{PM}_{10}\right)$ concentrations in Ouagadougou for measurement campaigns in 2018 (dry and rainy season) and 2019 (rainy season). PM mass concentrations were analyzed by hour, day and location. The characterization of traffic fleet composition was also described. The overall objective of this study was to address the present status of air pollution due to suspended particulate matter in Ouagadougou's city, ten years after the last status. It should be noted that this study covered more measurement sites than any previous study and was conducted over two years.

\section{Material and Methods}

\subsection{Description of Study Area and Sampling Points}

Ouagadougou the capital of Burkina Faso, located at $12^{\circ} 22$ North, $1^{\circ} 31$ West, $300 \mathrm{~m}$ above sea level, is situated in Sahelian region of West Africa. Its population was estimated at 1,700,000 in 2010 and 2,684,052 in 2020 by National Institute of Statistics and Demography. This corresponds to a population increase of $57.9 \%$. Thus, UN-HABITAT (UN-HABITAT, 2010) has renamed it the most dynamic city in the world. As the city is located in a warm semi-arid climate of Sahel, the climate consists of a dry season from October to May and a rainy season from June to September. During the rainy season, the rainfall ranged between $600-900 \mathrm{~mm}$, while the dry eight-month period generally receives less than $100 \mathrm{~mm}$ of rain (Lindén et al., 2012). Stable night-time atmospheric conditions are common at the beginning of the dry season in Ouagadougou (Lindén and Holmer, 2011), which are favorable to higher pollution levels (Boman et al., 2009). A study of the local wind field by (Lindén and Holmer, 2011) showed that wind speeds are generally very low in Ouagadougou, thus preventing good ventilation of urban air followed by the dispersion of pollutants emitted locally.

During the dry season, the influence of dust carried by Harmattan winds from Saharan desert in the North and North-East affects the entire Sahelian region and creates important seasonal differences in suspended particulate concentrations. The highest levels of airborne particulate matter are generally observed in February and the lowest levels in August (Prasad, 2011), (Titcombe and Simcik, 2011). According to Ouagadougou Meteorological Office, visibility is generally reduced by almost half during the dry season compared to the rainy season (DMN, 201AD).

PM measurements were carried out at fourteen (14) sampling sites (Figure 1) in 2018 and 2019 years. These sites can be divided into five (5) groups: 1) scholar sites (C3 and H6), 2) peripheral district sites (Kar, BV and G2), 3) industrial sites 


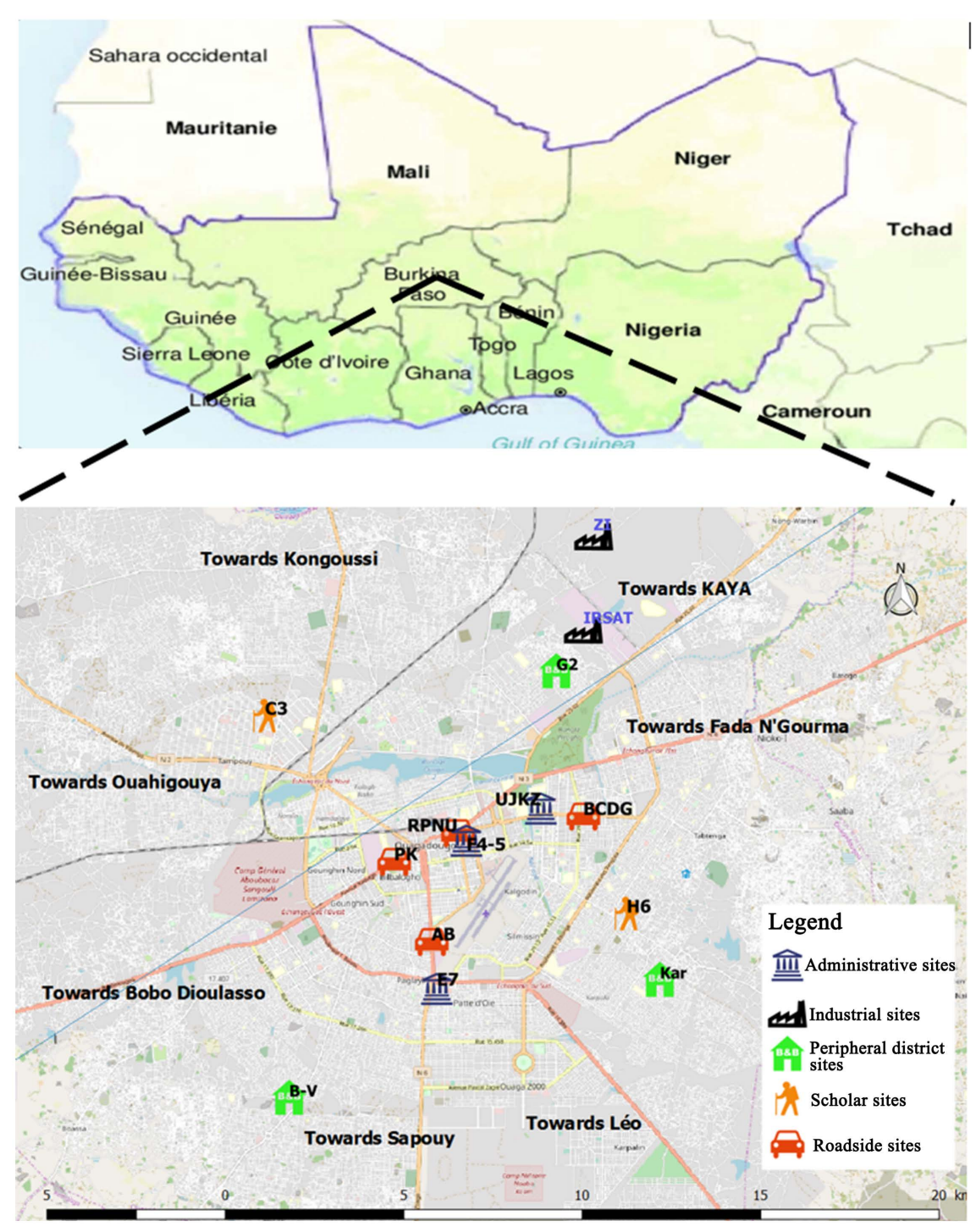

Figure 1. Particulate monitoring sites in Ouagadougou.

(IRSAT, ZI), 4) roadside sites with heavy traffic on paved roads (BCDG, PK, RPNU, AB), and 5) administrative sites (F4-5, E7, UJKZ). Three sites of 2018 campaign (F4-65, PK and RPNU) have not been not monitored in 2019 campaign. Data of G2's site were insufficient to represent 24 hours of measurement. Five sites (IRSAT, ZI, BV, Kar and UJKZ) were added in 2019 campaign. Sites were selected to cover as much of the city as possible. Table 1 presents the geographic coordinates of the sampling locations in Ouagadougou city.

\subsection{Road Traffic Characteristic}

In 2016, the Ouagadougou town hall has carried out a characterization of road traffic in the city of Ouagadougou by manual counting (Somda, 2018). About $1,003,997$ of daily displacements of people that enter and leave downtown. The distribution of vehicles is as follows: $74 \%$ motorized two-wheeled vehicles, $18 \%$ private vehicles, $7 \%$ transit vehicles and $1 \%$ heavy trucks. 
Table 1. Geographic coordinates of the sampling sites.

\begin{tabular}{|c|c|c|c|c|c|}
\hline $\mathrm{N}^{\bullet}$ & Sampling site & Longitude & Latitude & Site type & $\begin{array}{c}\text { Measurement } \\
\text { period }\end{array}$ \\
\hline 1 & E7*: ONATEL SUD & -1.524834347 & 12.33149065 & Administrative & $\begin{array}{l}2018-03-21 \\
2018-08-27 \\
2019-07-10\end{array}$ \\
\hline 2 & $\begin{array}{c}\text { F4-5*: Ministère de } \\
\text { l'Environnement de } \\
\text { l'Économie Verte et } \\
\text { du Changement } \\
\text { Climatique (MEEVCC) }\end{array}$ & -1.517218554 & 12.36967226 & Administrative & $\begin{array}{l}2018-03-15 \\
2018-08-24\end{array}$ \\
\hline 3 & $\begin{array}{l}\text { UJKZ: (Université } \\
\text { Joseph KI-ZERBO) }\end{array}$ & -1.498053 & 12.377978 & Administrative & 2019-09-17 \\
\hline 4 & $\begin{array}{c}\mathrm{AB}^{\star}: \text { SONABEL } \\
\text { Bassawarga }\end{array}$ & -1.526194454 & 12.3431663 & Roadside & $\begin{array}{l}2018-03-28 \\
2018-08-22 \\
2019-08-08\end{array}$ \\
\hline 5 & $\mathrm{PK}^{*}$ : Pont Kadiogo & -1.53587835 & 12.3638069 & Roadside & $\begin{array}{l}2018-03-30 \\
2018-08-09\end{array}$ \\
\hline 6 & $\begin{array}{l}\mathrm{RPNU}^{*} \text { : Rond-point } \\
\text { des Nations Unies }\end{array}$ & -1.5194297 & 12.37120785 & Roadside & $\begin{array}{l}2018-04-03 \\
2018-07-31\end{array}$ \\
\hline 7 & $\begin{array}{l}\text { BCDG }^{*} \text { : Boulevard } \\
\text { Charles De Gaulle }\end{array}$ & -1.4871354 & 12.37549121 & Roadside & $\begin{array}{l}2018-04-10 \\
2018-08-07 \\
2019-09-12\end{array}$ \\
\hline 8 & $\begin{array}{l}\text { C3*: Complexe } \\
\text { scolaire Notre dame } \\
\text { de l'espérance }\end{array}$ & -1.569103003 & 12.40132924 & Scholar & $\begin{array}{l}2018-19-04 \\
2018-08-23 \\
2019-09-04\end{array}$ \\
\hline 9 & $\begin{array}{c}\text { H6*: Complexe } \\
\text { scolaire Bon BERGER }\end{array}$ & -1.47595143 & 12.35034032 & Scholar & $\begin{array}{l}2018-17-04 \\
2018-08-20 \\
2019-08-26\end{array}$ \\
\hline 10 & BV: Bonheur-ville & -1.56288300 & 12.30300500 & $\begin{array}{l}\text { Peripheral } \\
\text { district }\end{array}$ & $2019-10-03$ \\
\hline 11 & Kar: Karpala & -1.46738100 & 12.33341900 & $\begin{array}{l}\text { Peripheral } \\
\text { district }\end{array}$ & 2019-06-10 \\
\hline 12 & $\begin{array}{l}\text { G2: Plateau } \\
\text { omnisports } \\
\text { de somgandé }\end{array}$ & -1.49405834 & 12.4129417 & $\begin{array}{l}\text { Peripheral } \\
\text { district }\end{array}$ & $\begin{array}{l}2018-03-27 \\
2018-08-14 \\
2019-10-01\end{array}$ \\
\hline 13 & $\begin{array}{l}\text { IRSAT: Institut de } \\
\text { Recherche en sciences } \\
\text { appliquées et } \\
\text { technologies (Kossodo) }\end{array}$ & -1.48709400 & 12.42494500 & Industrial & $2019-07-05$ \\
\hline 14 & $\begin{array}{l}\text { ZI: Zone industrielle } \\
\text { (Kossodo) }\end{array}$ & -1.484449 & 12.448949 & Industrial & 2019-06-30 \\
\hline
\end{tabular}

*These names were used in previous similar studies.

\subsection{Measurement Equipment}

An analyzer AEROCET 531S has been used. It is a mass profiler and particle counter combined in a small portable battery-powered unit. This analyzer 
measures particulate matter with diameters between 0.3 and $10.0 \mu \mathrm{m}$ and some others (total suspended particles). Its detection limit is $1.0 \mu \mathrm{g} \cdot \mathrm{m}^{-3}$.

\subsection{Measurement Methods}

Measurements of ambient air particulates concentrations were made at each sampling point during at least 12-hours and 48-hours during the measurement campaigns of 2018 and 2019, respectively. The AEROCET-531S was placed at a height of between 1.5 and 2 meters, which corresponds to the average position of the human airways. Each measurement consisted of one-minute concentrations of $\mathrm{PM}_{10}, \mathrm{PM}_{2.5}$ and $\mathrm{PM}_{1}$ and was recorded on a data storage card. Hourly and daily average concentrations reported here are arithmetic means of the respective 1-min readings in $\mu \mathrm{g} \cdot \mathrm{m}^{-3}$. The measurement relative uncertainties are deduced from the AEROCET measurement accuracy of $\pm 5 \%$. The calculations of the average concentrations and the measurement relative uncertainties were done by Microsoft Excel.

The Origin software, version 9 and the QSIS software, version 2.18.28, have been used for graphs and map, respectively.

It should be noted that in 2018 all measures lasted 12 hours. In 2019 at the sites (UJKZ, H6, ZI and B-V), measurements were taken during 48 hours continuously, 72 hours at the sites (BCDG, C3, Kar and G2), 96 hours at the sites (E7, $\mathrm{AB}$ and IRSAT). F4-5, RPNU and PK were not sampled in 2019.

\section{Results and Discussion}

Limit values for human exposure to particles recommended by the WHO, EEA or US EPA concern the 24-hour concentrations of $\mathrm{PM}_{2.5}$ and $\mathrm{PM}_{10}$. The results that will be presented and discussed will focus on these particles. Results concerning $\mathrm{PM}_{1}$ were also presented with respect to the fact that they have more significant human health effects. However, there are not recommended limits values.

The results will be discussed and will take into account the grouping made in the material and methods section.

\subsection{Hourly Concentrations Profiles}

\subsubsection{Hourly $\mathrm{PM}_{1}$ Concentrations}

Figure 2 presents the hourly concentration profiles obtained in 2019 campaign for $\mathrm{PM}_{1}$ in Ouagadougou city. These profiles are characterized by two obvious peaks between 3:00 - 8:00 am and 5:00 - 9:00 pm, respectively. These peaks can be explained on the one hand by the hours of heavy road traffic linked to the activities of the population and on the other hand by industrial activities on in there. It is important to note that large vehicles circulate in the city of Ouagadougou from $10 \mathrm{pm}$ to $5 \mathrm{am}$ (time allowed for these types of track vehicles). There is also the dynamics of the boundary layer $(\mathrm{BL})$, which results in high dilution rates during the day and low dilution rates at night (Lee et al., 2019). The peaks between 5:00 - 9:00 pm are more important than those between 5:00 - 8:00 am in 


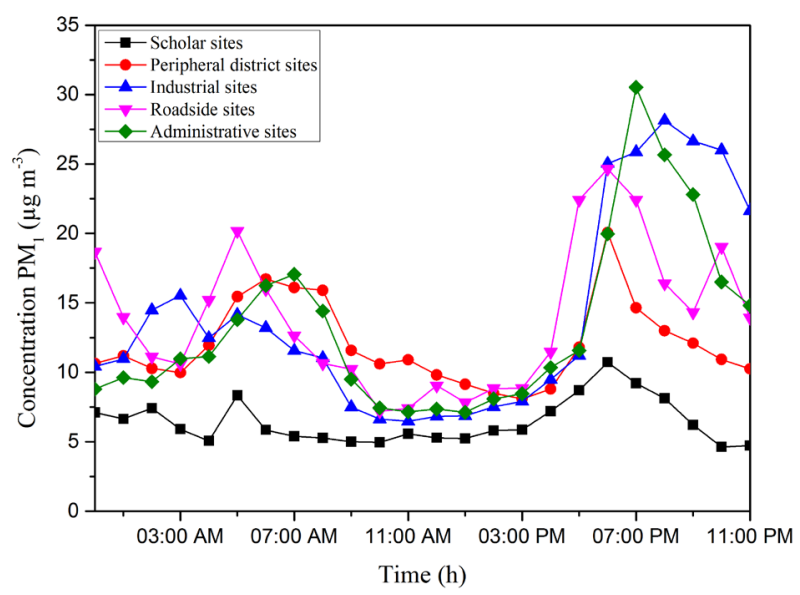

Figure 2. Profiles of 1-hour concentrations of $\mathrm{PM}_{1}$ obtained in rainy season (June-September) in 2019 (hours in local time HLT).

some sites. This could be explained by the increase in emissions during the evening, which stretches in a period when the BL is shallow as compared to the morning situation in which the height of the BL increases rapidly after sunrise. The $\mathrm{PM}_{1}$ concentration was $20 \pm 4$ and $17 \pm 3 \mu \mathrm{g} \cdot \mathrm{m}^{-3}$ for $2018 \mathrm{dry}$ season and 2018 rainy season, respectively. These values were similar to those obtained by Talbi and coauthors (Talbi, Kerchich, and Kerbachi, 2017) for Alger city. The hourly $\mathrm{PM}_{1}$ concentrations for educational institutions sites ranged from 5 to 11 $\mu \mathrm{g} \cdot \mathrm{m}^{-3}$, for peripheral district sites ranged from 8 to $20 \mu \mathrm{g} \cdot \mathrm{m}^{-3}$, for industrial sites ranged from 6 to $28 \mu \mathrm{g} \cdot \mathrm{m}^{-3}$, for roadside sites ranged from 7 to $25 \mu \mathrm{g} \cdot \mathrm{m}^{-3}$ and for administrative sites ranged from 7 to $30 \mu \mathrm{g} \cdot \mathrm{m}^{-3}$. These results highlight the importance of the activities of these sites except scholar ones on ultrafine particulates.

\subsubsection{Hourly $\mathrm{PM}_{2.5}$ Concentrations}

Figure 3 presents the profiles of 1-hour concentrations of $\mathrm{PM}_{2.5}$ obtained during the rainy season (June-September) in 2019 for the five sampling groups of sites. The profile of each group of sites exhibits two peaks: one during the morning (6:00 - 8:00 am) and the other during the afternoon (5:00 - 8:00 pm) except industrial sites and traffic sites which are marked by two morning peaks located respectively around 3:00 and 11:00 a.m. and 5:00 and 11:00 a.m. and afternoon's one. These observations are linked to the heavy traffic due to the start and end times of the administration's work and industrial activities. It should be noted that the populations of Ouagadougou have not yet adopted public transportation. The majority of them use single motorized two-wheeled vehicles. The 11:00 am peaks at the traffic sites can be explained on the one hand by the high level of traffic in connection with market and shop traffic, delivery activities and the activities of the various construction and demolition sites. On the other hand, the dynamics of the atmospheric boundary layer.

For scholar sites which holiday's period is in rainy season, the 1-hour concentrations don't vary practically from hour to hour. It should be noted that in the 


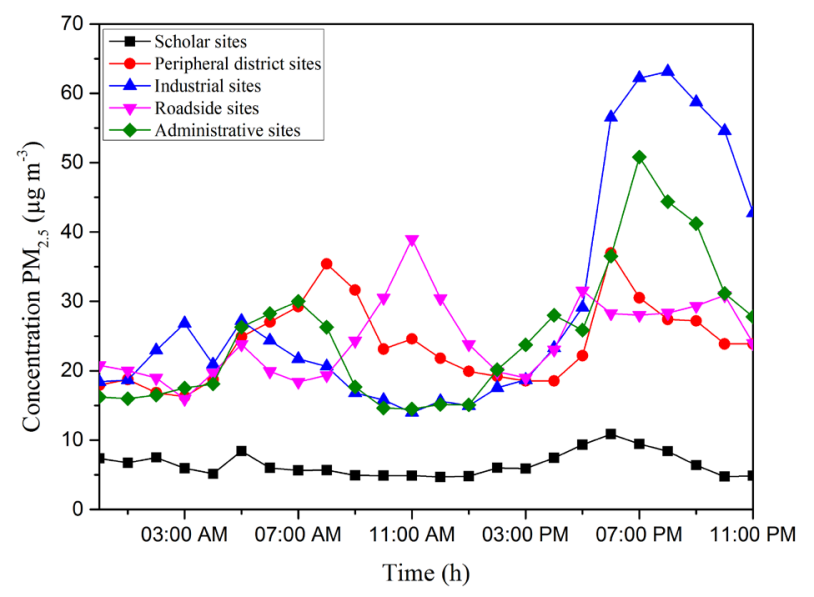

Figure 3. Profiles of 1-hour concentrations of $\mathrm{PM}_{2.5}$ obtained in rainy season (June-September) in 2019 (hours in local time HLT).

configuration of school sites, there is always a sports ground that serves as a sports training area. These playgrounds are even used by local residents during the holidays for sports. Hence, the observed concentrations, the low concentrations at the educational institutions sites can also be explained by the higher relative humidity and monthly rainfall observed during the measurement periods (70\% in August and 67\% in September) and $(5 \mathrm{~mm} /$ day in August and 2 $\mathrm{mm} /$ day in September) respectively compared to the other months of the year. High concentration values are observed for industrial sites at $8 \mathrm{pm}$ with a peak around 9:00 - 10:00 pm. This may be explained by the heavy traffic of large trucks in the industrial zone at these hours. Also, it should be noted that the roads in these areas are virtually unpaved. It must be added that in the industrial areas, some activities are (cement works, breweries, sawmills) done in the night coinciding with the measurement schedules. This contributes to the increase of the level of pollution in fine particles. Concerning residential dusty sites, $\mathrm{PM}_{2.5}$ concentration levels are high between 8:00 - 11:00 am and this is explained by the traffic and overcrowding in some areas of the city. For the case of administrative sites (E7 and UJKZ), it should be noted two peaks of the morning and evening rush hours corresponding to the morning work start time (7:00 am) and the evening work descent time around 5:00 pm. This gradual evolution can be explained by the increase in traffic related to the increased number of people visiting the administrative services. This finding is general with respect to African cities as pointed out by Petkova and coauthors (Petkova et al., 2013).

\subsubsection{Hourly $\mathrm{PM}_{10}$ Concentrations}

Figure 4 presents the profiles of 1-hour concentrations of $\mathrm{PM}_{10}$ obtained during the rainy season (June to September) 2019. Each of the sites exhibits scattered peaks in time. This is relatively linked to the different phenomena involved in the processes of emission and dispersion of the pollutants.

As previously, concentrations variation from hour to hour at scholar sites vary slightly. The profile of peripheral district sites exhibits an important peak of 


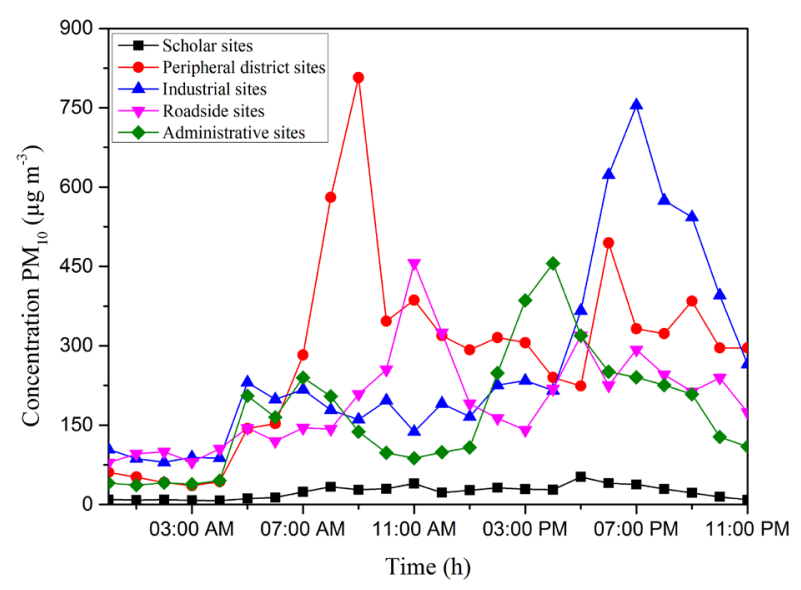

Figure 4. Profiles of 1-hour concentrations of $\mathrm{PM}_{10}$ obtained in rainy season (June-September) in 2019 (hours in local time HLT).

$\mathrm{PM}_{10}$ concentration between 8:00 - 11:00 am. Another peak, less important, is observed between 6:00 - 7:00 pm. These results are explained by the resuspension due to traffic on unpaved roads in these sites and high (respectively low) wind speed during the morning (respectively the evening). Residential dusty sites located near unpaved roads are characterized by important $\mathrm{PM}_{10}$ emissions. These areas are also characterized by extensive construction and demolition work, resulting in the re-suspension of dust. The profile of industrial sites shows peak around 9:00 - 10:00 pm corresponding to the heavy traffic of large trucks at these hours. The great gear causes a great re-suspension of dust. Roadside sites and administrative ones exhibited low $\mathrm{PM}_{10}$ concentration because they are associated to paved roads that not generate significant dust resuspension. However, a peak is observed around 11:00 am (respectively 4:00 pm) for roadside sites (respectively administrative sites) and related to worker's movements for lunch (respectively for worker's movement to home).

\subsection{4-Hour Concentrations}

Table 2 presents the 24-hour (daily) PM concentrations obtained during the rainy season (June to September) 2019. The results show that excepted scholar sites and despite the rainy season campaign, $\mathrm{PM}_{2.5}$ concentrations are close to recommended values whereas $\mathrm{PM}_{10}$ concentrations exceed three to five time the recommended limit by the WHO and European Environment Agency (EEA) and around two times the recommended limit by US EPA.

\subsection{Seasonal and Spatial Pollution Variability}

Tables 3-6 present results of descriptive statistics of hourly (or daily) of PM pollution levels for sampling sites. The percentage of hours in which recommended limits by US EPA, EEA, WHO and Burkina Faso (BFA) were exceeded is also presented.

The arithmetic means of hourly concentrations of PM are higher in dry season than rainy season (see lines 1 and 2 of Table 3 and Table 4). Indeed, the data in 
Table 2. 24-hour concentrations in 2019 rainy season.

\begin{tabular}{|c|c|c|c|c|c|c|}
\hline \multirow{2}{*}{ PM } & \multicolumn{6}{|c|}{ 24-hour PM concentrations $\left(\mu \mathrm{g} \cdot \mathrm{m}^{-3}\right)$} \\
\hline & Scholar sites & Peripheral district sites & Industrial sites & Roadside sites & Administrative sites & Recommended limits \\
\hline $\mathrm{PM}_{1}$ & $6 \pm 1$ & $12 \pm 3$ & $14 \pm 6$ & $14 \pm 4$ & $13 \pm 5$ & - \\
\hline $\mathrm{PM}_{2.5}$ & $6 \pm 1$ & $24 \pm 5$ & $29 \pm 14$ & $25 \pm 5$ & $25 \pm 9$ & $25^{\mathrm{a}}, 35^{\mathrm{b}}$ \\
\hline $\mathrm{PM}_{10}$ & $23 \pm 11$ & $281 \pm 154$ & $263 \pm 156$ & $195 \pm 77$ & $171 \pm 95$ & $50^{\mathrm{a}, \mathrm{c}}, 150^{\mathrm{b}}$ \\
\hline
\end{tabular}

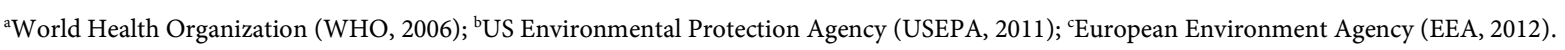

Table 3. Descriptive statistics of 1-hour concentrations of $\mathrm{PM}_{2.5}$ obtained from measurements in Ouagadougou, Burkina Faso, and percent of hours in which recommended limits of $35 \mu \mathrm{g} \cdot \mathrm{m}^{-3}$ by USEPA, of $25 \mu \mathrm{g} \cdot \mathrm{m}^{-3}$ by WHO and of $300 \mu \mathrm{g} \cdot \mathrm{m}^{-3} \mathrm{by}$ BFA were exceeded. $s d=$ standard deviation; nd = not determined. For each site, the data of the first line corresponds to measurements results of 2018 dry season (March-May); the second line to measurements results of 2018 rainy season (June-September); and the third line to measurements results of 2019 rainy season (June-September).

\begin{tabular}{|c|c|c|c|c|c|c|c|c|c|}
\hline \multirow{2}{*}{ Site (type) } & \multirow{2}{*}{$\begin{array}{c}\text { Mean } \pm s d \\
\left(\mu g \cdot m^{-3}\right)\end{array}$} & \multirow{2}{*}{$\begin{array}{l}\text { Minimum } \\
\left(\mu \mathrm{g} \cdot \mathrm{m}^{-3}\right)\end{array}$} & \multirow{2}{*}{$\underset{\left(\mu \mathrm{g} \cdot \mathrm{m}^{-3}\right)}{\text { Maximum }}$} & \multirow{2}{*}{$\begin{array}{l}\text { Median } \\
\left(\mu \mathrm{g} \cdot \mathrm{m}^{-3}\right)\end{array}$} & \multirow{2}{*}{$\begin{array}{l}\text { Number of } \\
\text { measures }\end{array}$} & \multirow{2}{*}{$\begin{array}{c}\text { Measurement } \\
\text { duration }\end{array}$} & \multicolumn{3}{|c|}{$\begin{array}{l}\text { Percentage of 1-hour concentrations } \\
\text { higher than recommended limit }\end{array}$} \\
\hline & & & & & & & USPEA & WHO & BFA \\
\hline \multirow{3}{*}{$\begin{array}{l}\text { E7: ONATEL SUD } \\
\text { (Administrative) }\end{array}$} & $46.3 \pm 2.7$ & 26.7 & 144.3 & 42.3 & 517 & $12 \mathrm{~h}$ & 82.8 & 100 & 88.4 \\
\hline & $11.2 \pm 0.8$ & 3.1 & 42.2 & 10.5 & 606 & $12 \mathrm{~h}$ & 0.2 & 0.3 & 0.2 \\
\hline & $29.3 \pm 0.9$ & 13.9 & 121.5 & 24.6 & 428 & 4 days & 20.7 & 47.3 & 23.2 \\
\hline \multirow{3}{*}{$\begin{array}{l}\text { F4-5: MEEVCC } \\
\text { (Administrative) }\end{array}$} & $39.6 \pm 5.6$ & 15.0 & 706.1 & 30.2 & 774 & $12 \mathrm{~h}$ & 68.0 & 38.6 & 74.3 \\
\hline & $19.8 \pm 1.5$ & 6.7 & 115.0 & 16.5 & 748 & $12 \mathrm{~h}$ & 8.4 & 23.9 & 21.3 \\
\hline & nd & nd & nd & nd & nd & nd & nd & nd & nd \\
\hline \multirow{3}{*}{$\begin{array}{c}\text { UJKZ: Université } \\
\text { Joseph KI-ZERBO } \\
\text { (Administrative) }\end{array}$} & nd & nd & nd & nd & nd & $12 \mathrm{~h}$ & nd & nd & nd \\
\hline & nd & nd & nd & nd & nd & $12 \mathrm{~h}$ & nd & nd & nd \\
\hline & $21.5 \pm 0.8$ & 5.7 & 86.1 & 19.4 & 3121 & 2 days & 13.5 & 28.9 & 21.3 \\
\hline \multirow{3}{*}{$\begin{array}{l}\text { AB: SONABEL } \\
\text { Bassawarga } \\
\text { (roadside) }\end{array}$} & $61.3 \pm 5.8$ & 16.3 & 256.1 & 51.1 & 516 & $12 \mathrm{~h}$ & 74.0 & 90.7 & 98.6 \\
\hline & $21.1 \pm 2.0$ & 7 & 187 & 19.2 & 568 & $12 \mathrm{~h}$ & 7.2 & 25.5 & 14.4 \\
\hline & $14.9 \pm 0.7$ & 0.8 & 291.9 & 11.6 & 6.21 & 5 days & 8.5 & 18.3 & 7.9 \\
\hline \multirow{3}{*}{$\begin{array}{l}\text { PK: Pont Kadiogo } \\
\quad \text { (roadside) }\end{array}$} & $79.5 \pm 4.5$ & 53.5 & 227.8 & 73.5 & 484 & $12 \mathrm{~h}$ & 100 & 100 & 99.8 \\
\hline & $25.6 \pm 2.1$ & 8.3 & 68.7 & 24 & 543 & $12 \mathrm{~h}$ & 21.2 & 43.5 & 17.5 \\
\hline & nd & nd & nd & nd & nd & nd & nd & nd & nd \\
\hline RPNU: United & $182.9 \pm 6.2$ & 143.4 & 296.6 & 167.5 & 499 & $12 \mathrm{~h}$ & 99.8 & 100 & 100 \\
\hline \multirow{2}{*}{$\begin{array}{l}\text { Nation roundabout } \\
\quad \text { (roadside) }\end{array}$} & $34.1 \pm 1.4$ & 20.3 & 63.4 & 32.5 & 476 & $12 \mathrm{~h}$ & 35.7 & 93.3 & 21.2 \\
\hline & nd & nd & nd & nd & nd & nd & nd & $\mathrm{Nd}$ & nd \\
\hline \multirow{3}{*}{$\begin{array}{c}\text { BCDG: Bd. Charles } \\
\text { De Gaulle } \\
\text { (roadside) }\end{array}$} & $57.9 \pm 2.7$ & 33.9 & 122.7 & 55.1 & 491 & $12 \mathrm{~h}$ & 99.4 & 100 & 83.5 \\
\hline & $14.6 \pm 1.4$ & 5.0 & 42.4 & 11.8 & 437 & $12 \mathrm{~h}$ & 3.2 & 11.2 & 0.7 \\
\hline & $25.4 \pm 1.1$ & 6.5 & 604.0 & 22.3 & 4565 & 3 days & 17.7 & 41.5 & 15.7 \\
\hline \multirow{3}{*}{$\begin{array}{l}\text { C3: Complexe scolaire } \\
\text { Notre dame de } \\
\text { l'espérance (scholar) }\end{array}$} & $56.2 \pm 4.4$ & 30.7 & 333.9 & 43.2 & 766 & $12 \mathrm{~h}$ & 87.1 & 100 & 98.4 \\
\hline & $15.8 \pm 1.2$ & 5.7 & 68.2 & 13.3 & 964 & $12 \mathrm{~h}$ & 3.4 & 10.8 & 4.6 \\
\hline & $8.4 \pm 0.3$ & 0.9 & 39.1 & 7.2 & 3863 & 3 days & 0.2 & 1.8 & 0.8 \\
\hline \multirow{3}{*}{$\begin{array}{c}\text { H6: Complexe } \\
\text { scolaire Bon BERGER } \\
\text { (scholar) }\end{array}$} & $88.3 \pm 10.8$ & 31.6 & 395.7 & 55.1 & 491 & $12 \mathrm{~h}$ & 98.3 & 100 & 97.3 \\
\hline & $15.2 \pm 1.3$ & 5.4 & 52.4 & 11.8 & 437 & $12 \mathrm{~h}$ & 3.8 & 14.4 & 2.0 \\
\hline & $4.9 \pm 0.2$ & 0.3 & 13.2 & 22.3 & 4565 & 2 days & 0.0 & 0.0 & 0.0 \\
\hline \multirow{3}{*}{$\begin{array}{l}\text { B-V: Bonheur-ville } \\
\text { (peripheral district) }\end{array}$} & nd & nd & nd & nd & nd & $12 \mathrm{~h}$ & nd & nd & nd \\
\hline & nd & nd & nd & nd & nd & $12 \mathrm{~h}$ & nd & nd & nd \\
\hline & $22.6 \pm 1.1$ & 7.1 & 177.3 & 19.3 & 1899 & 2 days & 9.7 & 27.8 & 32.5 \\
\hline
\end{tabular}


Continued

\begin{tabular}{cccccccccc}
\hline Kar: Karpala & nd & nd & nd & nd & nd & $12 \mathrm{~h}$ & nd & nd & nd \\
(peripheral district) & nd & nd & nd & nd & nd & $12 \mathrm{~h}$ & nd & nd & nd \\
& $23.6 \pm 0.7$ & 11.1 & 277 & 21.5 & 2712 & 5 days & 6.3 & 33.0 & 39.0 \\
G2: Plateau & $57.7 \pm 6.2$ & 20.3 & 228.9 & 46.4 & 481 & $12 \mathrm{~h}$ & 77.8 & 95.0 & 96.5 \\
Omnisportde & $18.8 \pm 1.7$ & 27.2 & 59.9 & 15.7 & 535 & $12 \mathrm{~h}$ & 8.2 & 22.8 & 8.4 \\
Somgandé (Residential) & $27.0 \pm 1.4$ & 10.5 & 113.8 & 19.4 & 2457 & 3 days & 26.5 & 35.1 & 19.1 \\
& & & & & & & & & \\
IRSAT-Kossodo & nd & nd & nd & nd & nd & $12 \mathrm{~h}$ & nd & nd & nd \\
(industrial) & $28.9 \pm 1.0$ & 8.9 & 355.4 & 22.4 & 5339 & 4 days & 20.1 & 39.9 & 23.8 \\
ZI: Zone & nd & nd & nd & nd & nd & $12 \mathrm{~h}$ & nd & nd & nd \\
Industrielle-Kossodo & nd & nd & nd & nd & nd & $12 \mathrm{~h}$ & nd & nd & nd \\
(industrial) & $26.0 \pm 0.9$ & 11.6 & 236.4 & 23.5 & 2879 & 5 days & 18.0 & 41.5 & 14.7 \\
\hline
\end{tabular}

Table 4. Descriptive statistics of 1-hour concentrations of $\mathrm{PM}_{10}$ obtained from measurements in Ouagadougou, Burkina Faso, and percent of hours in which recommended limits of $150 \mu \mathrm{g} \cdot \mathrm{m}^{-3}$ by USEPA, of $50 \mu \mathrm{g} \cdot \mathrm{m}^{-3}$ by EEA, of $50 \mu \mathrm{g} \cdot \mathrm{m}^{-3} \mathrm{by} \mathrm{WHO}$ and of 300 $\mu \mathrm{g} \cdot \mathrm{m}^{-3}$ by FA were exceeded. $\mathrm{sd}=$ standard deviation; $\mathrm{nd}=$ not determined. For each site, the data of the first line corresponds to measurements results of 2018 dry season (March-May); the second line to measurements results of 2018 rainy season (June-September); and the third line to measurements results of 2019 rainy season (June-September).

\begin{tabular}{|c|c|c|c|c|c|c|c|c|c|}
\hline \multirow[t]{2}{*}{ Site (type) } & \multirow{2}{*}{$\begin{array}{c}\text { Mean } \pm s d \\
\left(\mu g \cdot m^{-3}\right)\end{array}$} & \multirow{2}{*}{$\begin{array}{l}\text { Minimum } \\
\left(\mu \mathrm{g} \cdot \mathrm{m}^{-3}\right)\end{array}$} & \multirow{2}{*}{$\begin{array}{l}\text { Maximum } \\
\left(\mu \mathrm{g} \cdot \mathrm{m}^{-3}\right)\end{array}$} & \multirow{2}{*}{$\begin{array}{l}\text { Median } \\
\left(\mu g \cdot \mathrm{m}^{-3}\right)\end{array}$} & \multirow{2}{*}{$\begin{array}{l}\text { Number of } \\
\text { measures }\end{array}$} & \multirow{2}{*}{$\begin{array}{l}\text { Measurement } \\
\text { duration }\end{array}$} & \multicolumn{3}{|c|}{$\begin{array}{l}\text { Percentage of 1-hour concentrations } \\
\text { higher than recommended limit }\end{array}$} \\
\hline & & & & & & & USPEA & WHO & BFA \\
\hline \multirow{3}{*}{$\begin{array}{l}\text { E7: ONATEL SUD } \\
\text { (Administrative) }\end{array}$} & $545.1 \pm 71.3$ & 95.9 & 3676.9 & 426.7 & 517 & $12 \mathrm{~h}$ & 95.9 & 100 & 88.4 \\
\hline & $55.2 \pm 5.1$ & 10 & 244.2 & 49.2 & 606 & $12 \mathrm{~h}$ & 1.0 & 49.5 & 0.2 \\
\hline & $223.7 \pm 10.5$ & 27.8 & 2787.2 & 171.5 & 4276 & 4 days & 57.2 & 96.8 & 23.2 \\
\hline \multirow{3}{*}{$\begin{array}{l}\text { F4-5: MEEVCC } \\
\text { (Administrative) }\end{array}$} & $435.6 \pm 102.4$ & 104.8 & 13,484 & 293 & 744 & $12 \mathrm{~h}$ & 91.8 & 100 & 74.3 \\
\hline & $163.4 \pm 18.9$ & 48.6 & 2260.5 & 140.85 & 748 & $12 \mathrm{~h}$ & 44.1 & 99.9 & 21.3 \\
\hline & nd & nd & nd & nd & nd & nd & nd & nd & nd \\
\hline UJKZ: Université & nd & nd & nd & nd & nd & $12 \mathrm{~h}$ & nd & nd & nd \\
\hline Joseph KI-ZERBO & nd & nd & nd & nd & nd & $12 \mathrm{~h}$ & nd & nd & nd \\
\hline (Administrative) & $211.1 \pm 16.8$ & 16.6 & 2337.9 & 129.2 & 3121 & 2 days & 43.9 & 86.4 & 21.3 \\
\hline AB: SONABEL & $859.5 \pm 97.2$ & 155.2 & 4433.4 & 753.9 & 516 & $12 \mathrm{~h}$ & 100 & 100 & 98.6 \\
\hline Bassawarga & $127.6 \pm 16.3$ & 23.1 & 754.4 & 99.55 & 568 & $12 \mathrm{~h}$ & 24.8 & 88.0 & 14.4 \\
\hline (roadside) & $104.3 \pm 8.7$ & 1 & 6097.2 & 39.6 & 6214 & 5 days & 24.8 & 47.1 & 7.9 \\
\hline \multirow{3}{*}{$\begin{array}{l}\text { PK: Pont Kadiogo } \\
\quad \text { (roadside) }\end{array}$} & $613.5 \pm 102.1$ & 259.9 & 3433.6 & 445.9 & 484 & $12 \mathrm{~h}$ & 100 & 100 & 99.8 \\
\hline & $143.7 \pm 16.4$ & 28.1 & 565.6 & 113.6 & 543 & $12 \mathrm{~h}$ & 36.1 & 89.0 & 17.5 \\
\hline & nd & nd & nd & nd & nd & nd & nd & $\mathrm{Nd}$ & nd \\
\hline RPNU: United & $1311.3 \pm 69.1$ & 711.6 & 2553.8 & 1148.8 & 499 & $12 \mathrm{~h}$ & 100 & 100 & 100 \\
\hline \multirow{2}{*}{$\begin{array}{l}\text { Nation roundabout } \\
\text { (roadside) }\end{array}$} & $231.7 \pm 17.0$ & 74.2 & 710 & 207.55 & 476 & $12 \mathrm{~h}$ & 84.5 & 100 & 21.2 \\
\hline & nd & nd & nd & nd & nd & nd & nd & $\mathrm{Nd}$ & nd \\
\hline \multirow{3}{*}{$\begin{array}{l}\text { BCDG: Bd.Charles } \\
\text { De Gaulle (roadside) }\end{array}$} & $487.3 \pm 57.3$ & 120.9 & 2242.8 & 377.8 & 491 & $12 \mathrm{~h}$ & 98.9 & 100 & 83.5 \\
\hline & $60.9 \pm 7.6$ & 11.8 & 420 & 50.3 & 437 & $12 \mathrm{~h}$ & 3.9 & 50.8 & 0.7 \\
\hline & $188.2 \pm 24.3$ & 24.9 & $17,811.4$ & 115.9 & 4565 & 3 days & 40.8 & 85.5 & 15.7 \\
\hline C3: Complexe scolaire & $671.3 \pm 83.2$ & 196.6 & 6357.6 & 477.6 & 766 & $12 \mathrm{~h}$ & 100 & 100 & 98.4 \\
\hline Notre dame de & $103.7 \pm 7.2$ & 29.9 & 523.8 & 95.8 & 964 & $12 \mathrm{~h}$ & 13.5 & 85.6 & 4.6 \\
\hline l'espérance (scholar) & $41.1 \pm 1.5$ & 1.2 & 873.5 & 24.4 & 3,863 & 3 days & 4.9 & 22.5 & 0.8 \\
\hline H6: Complexe & $1278.8 \pm 220$ & 179.8 & $10,200.5$ & 648.3 & 715 & $12 \mathrm{~h}$ & 100 & 100 & 97.3 \\
\hline scolaire Bon & $100.6 \pm 5.8$ & 25.3 & 276.1 & 91.3 & 758 & $12 \mathrm{~h}$ & 10.0 & 96.2 & 2.0 \\
\hline BERGER (scholar) & $12.8 \pm 1.0$ & 05 & 305.6 & 8.3 & 3160 & 2 days & 0.1 & 1.4 & 0.0 \\
\hline
\end{tabular}




\section{Continued}

\begin{tabular}{|c|c|c|c|c|c|c|c|c|c|}
\hline \multirow{3}{*}{$\begin{array}{l}\text { B-V: Bonheur-ville } \\
\text { (peripheral district) }\end{array}$} & nd & nd & nd & nd & nd & $12 \mathrm{~h}$ & nd & nd & nd \\
\hline & nd & nd & nd & nd & nd & $12 \mathrm{~h}$ & nd & nd & nd \\
\hline & $270.6 \pm 28.6$ & 22.1 & 6420.5 & 202.6 & 1899 & 2 days & 59.0 & 85.7 & 32.5 \\
\hline \multirow{3}{*}{$\begin{array}{c}\text { Kar: Karpala } \\
\text { (peripheral district) }\end{array}$} & nd & nd & nd & nd & nd & $12 \mathrm{~h}$ & nd & nd & nd \\
\hline & nd & nd & nd & nd & nd & $12 \mathrm{~h}$ & nd & nd & nd \\
\hline & $226.6 \pm 45.4$ & 27.9 & $29,300.3$ & 191.95 & 2712 & 5 days & 61.8 & 86.6 & 39.1 \\
\hline G2: Plateau Omnisport & $766.8 \pm 118.8$ & 176 & 4532.4 & 559 & 481 & $12 \mathrm{~h}$ & 100 & 100 & 96.5 \\
\hline de Somgandé & $88.2 \pm 14.0$ & 18.4 & 694.1 & 57.9 & 535 & $12 \mathrm{~h}$ & 15.7 & 58.7 & 8.4 \\
\hline (Residential) & $177.6 \pm 12.3$ & 18.5 & 687.2 & 117.8 & 2457 & 3 days & 39.0 & 86.6 & 19.1 \\
\hline \multirow{3}{*}{$\begin{array}{l}\text { IRSAT-Kossodo } \\
\quad \text { (industrial) }\end{array}$} & nd & nd & nd & nd & nd & $12 \mathrm{~h}$ & nd & nd & nd \\
\hline & nd & nd & nd & nd & nd & $12 \mathrm{~h}$ & nd & nd & nd \\
\hline & $250.7 \pm 16.4$ & 21.9 & $11,031.9$ & 157 & 5339 & 4 days & 52.3 & 90.1 & 23.8 \\
\hline ZI: Zone & nd & nd & nd & nd & nd & $12 \mathrm{~h}$ & nd & nd & nd \\
\hline Industrielle-Kossodo & nd & nd & nd & nd & nd & $12 \mathrm{~h}$ & nd & nd & nd \\
\hline (indsutrial) & $191.8 \pm 17.2$ & 28.4 & 6122.2 & 139 & 2879 & 5 days & 46.0 & 89.5 & 14.7 \\
\hline
\end{tabular}

Table 5. Descriptive statistics of 24-hour concentrations of $\mathrm{PM}_{2.5}$ obtained from measurements of 2019 rainy season (June to September) in Ouagadougou, Burkina Faso, and percent of hours in which recommended limits $35 \mu \mathrm{g} \cdot \mathrm{m}^{-3} \mathrm{by} \mathrm{USEPA}, \mathrm{of} 25 \mu \mathrm{g} \cdot \mathrm{m}^{-3} \mathrm{by}$ EEA, of $25 \mu \mathrm{g} \cdot \mathrm{m}^{-3}$ by WHO and of $300 \mu \mathrm{g} \cdot \mathrm{m}^{-3}$ by BFA were exceeded. sd = standard deviation.

\begin{tabular}{|c|c|c|c|c|c|c|c|c|}
\hline \multirow[t]{2}{*}{ Site (type) } & \multirow{2}{*}{$\begin{array}{c}\text { Mean } \pm \mathrm{sd} \\
\left(\mu \mathrm{g} \cdot \mathrm{m}^{-3}\right)\end{array}$} & \multirow{2}{*}{$\begin{array}{c}\text { Minimum } \\
\left(\mu \mathrm{g} \cdot \mathrm{m}^{-3}\right)\end{array}$} & \multirow{2}{*}{$\begin{array}{l}\text { Maximum } \\
\left(\mu \mathrm{g} \cdot \mathrm{m}^{-3}\right)\end{array}$} & \multirow{2}{*}{$\begin{array}{l}\text { Median } \\
\left(\mu \mathrm{g} \cdot \mathrm{m}^{-3}\right)\end{array}$} & \multirow{2}{*}{$\begin{array}{l}\text { Number } \\
\text { of measures - }\end{array}$} & \multicolumn{3}{|c|}{$\begin{array}{l}\text { Percentage of } 24 \text {-hour concentrations } \\
\text { higher than recommended limit }\end{array}$} \\
\hline & & & & & & USPEA & WHO & BFA \\
\hline E7: ONATEL SUD (Administrative) & $27.5 \pm 8.0$ & 17.7 & 54.0 & 24.7 & 24 & 20.8 & 50 & 0.0 \\
\hline $\begin{array}{l}\text { UJKZ: Université Joseph KI-ZERBO } \\
\text { (Administrative) }\end{array}$ & $22.6 \pm 10.6$ & 7.9 & 47.6 & 22.5 & 24 & 12.5 & 45.8 & 0.0 \\
\hline AB: SONABEL Bassawarga (roadside) & $27.2 \pm 11.0$ & 10.5 & 66.7 & 22.7 & 24 & 20.8 & 45.8 & 0.0 \\
\hline BCDG: Bd. Charles De Gaulle (roadside) & $21.7 \pm 9.4$ & 9.5 & 41.1 & 17.3 & 24 & 20.8 & 37.5 & 0.0 \\
\hline $\begin{array}{l}\text { C3: Complexe scolaire Notre dam } \\
\text { de l'espérance (scholar) }\end{array}$ & $7.8 \pm 2.1$ & 2.3 & 12.0 & 7.5 & 24 & 0.0 & 0.0 & 0.0 \\
\hline $\begin{array}{l}\text { H6: Complexe scolaire } \\
\text { Bon BERGER (scholar) }\end{array}$ & $5.2 \pm 1.4$ & 2.8 & 9.7 & 5.0 & 24 & 0.0 & 0.0 & 0.0 \\
\hline B-V: Bonheur-ville (peripheral district) & $23.1 \pm 7.2$ & 13.5 & 48.8 & 20.3 & 24 & 12.5 & 29.2 & 0.0 \\
\hline Kar: Karpala (peripheral district) & $24.8 \pm 5.7$ & 17.0 & 42.9 & 22.9 & 24 & 4.2 & 37.5 & 0.0 \\
\hline IRSAT-Kossodo (industrial) & $35.0 \pm 24.2$ & 12.5 & 100.0 & 21.7 & 24 & 25 & 41.7 & 0.0 \\
\hline $\begin{array}{l}\text { ZI: Zone industrielle-Kossodo } \\
\text { (industrial) }\end{array}$ & $23.8 \pm 9.4$ & 13.5 & 60.3 & 20.7 & 24 & 8.3 & 33.3 & 0.0 \\
\hline All & $21.9 \pm 8.9$ & 2.8 & 100.0 & 18.5 & 24 & 12.5 & 32.1 & 0.0 \\
\hline
\end{tabular}

Table 6. Descriptive statistics of 24-hour concentrations of $\mathrm{PM}_{10}$ obtained from measurements of 2019 rainy season (June to September) in Ouagadougou, Burkina Faso, and percent of hours in which recommended limits of $150 \mu \mathrm{g} \cdot \mathrm{m}^{-3} \mathrm{by} \mathrm{USEPA}$, of 50 $\mu \mathrm{g} \cdot \mathrm{m}^{-3}$ by EEA, of $50 \mu \mathrm{g} \cdot \mathrm{m}^{-3}$ by WHO and of $300 \mu \mathrm{g} \cdot \mathrm{m}^{-3}$ by BFA were exceeded. $\mathrm{sd}=$ standard deviation.

\begin{tabular}{|c|c|c|c|c|c|c|c|c|}
\hline \multirow[t]{2}{*}{ Site (type) } & \multirow{2}{*}{$\begin{array}{c}\text { Mean } \pm \text { sd } \\
\left(\mu \mathrm{g} \cdot \mathrm{m}^{-3}\right)\end{array}$} & \multirow{2}{*}{$\begin{array}{c}\text { Minimum } \\
\left(\mu \mathrm{g} \cdot \mathrm{m}^{-3}\right)\end{array}$} & \multirow{2}{*}{$\begin{array}{c}\text { Maximum } \\
\left(\mu \mathrm{g} \cdot \mathrm{m}^{-3}\right)\end{array}$} & \multirow{2}{*}{$\begin{array}{l}\text { Median } \\
\left(\mu \mathrm{g} \cdot \mathrm{m}^{-3}\right)\end{array}$} & \multirow{2}{*}{$\begin{array}{l}\text { Number } \\
\text { of measures- }\end{array}$} & \multicolumn{3}{|c|}{$\begin{array}{l}\text { Percentage of 24-hour concentrations } \\
\text { higher than recommended limit }\end{array}$} \\
\hline & & & & & & USPEA & WHO & BFA \\
\hline E7: ONATEL SUD (Administrative) & $50.0 \pm 7.8$ & 31.5 & 102.6 & 45.2 & 24 & 0.0 & 37.5 & 0.0 \\
\hline
\end{tabular}




\section{Continued}

\begin{tabular}{|c|c|c|c|c|c|c|c|c|}
\hline $\begin{array}{c}\text { UJKZ: Université Joseph KI-ZERBO } \\
\text { (Administrative) }\end{array}$ & $293.0 \pm 92.7$ & 35.7 & 866.2 & 255.5 & 24 & 75 & 83.3 & 45.8 \\
\hline AB: SONABEL Bassawarga (roadside) & $199.5 \pm 64.5$ & 23.0 & 741.2 & 156.0 & 24 & 58.3 & 95.8 & 16.7 \\
\hline BCDG: Bd. Charles De Gaulle (roadside) & $190.3 \pm 65.3$ & 38.2 & 529.7 & 113.1 & 24 & 41.7 & 87.5 & 25 \\
\hline $\begin{array}{c}\text { C3: Complexe scolaire Notre dame de } \\
\text { l'espérance (scholar) }\end{array}$ & $31.1 \pm 7.5$ & 9.4 & 83.3 & 31.7 & 24 & 0.0 & 8.3 & 0.0 \\
\hline $\begin{array}{l}\text { H6: Complexe scolaire Bon BERGER } \\
\text { (scholar) }\end{array}$ & $15.9 \pm 4.4$ & 4.0 & 44.8 & 16.3 & 24 & 0.0 & 0.0 & 0.0 \\
\hline B-V: Bonheur-ville (peripheral district) & $309.4 \pm 95.5$ & 21.2 & 873.1 & 330.8 & 24 & 70.8 & 83.3 & 54.2 \\
\hline Kar: Karpala (peripheral district) & $253.5 \pm 98.6$ & 43.3 & 1224.7 & 241.0 & 24 & 70.8 & 91.7 & 16.7 \\
\hline IRSAT-Kossodo (industrial) & $318.1 \pm 120.8$ & 34.6 & 1009.7 & 232.1 & 24 & 70.8 & 87.5 & 29.2 \\
\hline $\begin{array}{l}\text { ZI: Zone industrielle-Kossodo } \\
\text { (industrial) }\end{array}$ & $208.6 \pm 81.9$ & 34.6 & 779.6 & 141.2 & 24 & 45.8 & 91.7 & 12.5 \\
\hline All & $186.9 \pm 63.9$ & 4.0 & 1224.7 & 148.6 & 240 & 25 & 68.8 & 38.8 \\
\hline
\end{tabular}

the second column show that the concentrations in the 2018 dry season are higher than the concentrations of the two measurements in 2018 and 2019 rainy seasons for all sampled sites. This result shows a seasonal variability of PM pollution level. Concentration values significantly vary from a site category (scholar, roadside, administrative, peripheral district or industrial) to another (see Figures 2-4) and Table 3 and Table 4. As previously, this result shows a spatial variability of PM pollution level.

Concerning the daily concentration, where only measurements realized during the rainy season in 2019 (Table 5 and Table 6), the arithmetic means of $\mathrm{PM}_{2.5}$ (respectively $\mathrm{PM}_{10}$ ) concentrations varied from 5.2 to $35.0 \mu \mathrm{g} \cdot \mathrm{m}^{-3}$ (respectively 15.9 to $318.1 \mu \mathrm{g} \cdot \mathrm{m}^{-3}$ ) overall sites. For all sites, the average percentage of 24-hour concentrations higher than the WHO recommended limit of $\mathrm{PM}_{2.5}$ (respectively $\mathrm{PM}_{10}$ ) is about $32 \%$ (respectively $69 \%$ ). This means that the $\mathrm{PM}_{10}$ pollution in Ouagadougou is more acute than the $\mathrm{PM}_{2.5}$ pollution. Concerning the $\mathrm{PM}_{10}, 69 \%$ means that each people of Ouagadougou is each day exposure to 16 hours of pollution level higher than the WHO recommended limit.

Based on Table 2, except scholar sites, the other ones (roadside, administrative, peripheral district or industrial) are significantly influenced by combustion and resuspension processes resulting in relatively higher concentrations of $\mathrm{PM}_{2.5}$ and $\mathrm{PM}_{10}$. The traffic proximity sites are influenced by traffic exhaust emission which is a significant source of fine and ultra-fine particles. In the whole city during the dry season other sources come into play such as the dust carried by Harmattan from Sahara and the Bodélés depression in Chad, the suspension by the wind of local dust, during all seasons the use of biomass as domestic energy and the incineration of waste in open spaces. During the rainy season, the scenario does not change for fines and ultra-fines but the traffic proximity sites will be more polluted with $\mathrm{PM}_{10}$ than those of urban administrative ones. From the dry 
season to the rainy season the ultra-fine particles undergo a very low variability. This may suggest that they come mainly from traffic. Indeed, the activity of this source may not change significantly from a season to another. For $\mathrm{PM}_{2.5}$ and $\mathrm{PM}_{10}$, their concentrations are subject to different degrees of variability. This would suggest attenuation, extinguishment, or reduction of the contribution of some sources of these sizes of particles, and that these two categories of particulate matter would be added by all other sources in addition to those cited above. It has been observed the effect of the season on particulate matter concentrations over the city of Ouagadougou. Particulate matter concentrations are attenuated by rainfall by leaching air from a large part of these particles especially coarse.

During the dry season, the influence of dust carried by Harmattan winds from the Sahara Desert in the North and North-East affects the entire Sahelian region and creates important seasonal differences in suspended particulate concentrations.

The results also indicate that the PM concentrations vary depending on the type of site and from the rainy to the dry season. It appears that PM pollution levels are higher in the dry season than in the rainy season. These results show the seasonal and spatial variability of PM pollution levels. There are several reasons for these results. On the one hand, the road network on the outskirts of the city (unpaved roads), the mode of transport of the inhabitants on the outskirts (individual transport) and the lack of rain that enhances the activity of other sources including the re-suspension of local dust by the wind. It is important to note that these pollution levels change with particle size. The amplitudes of concentrations are not the same but the fine particles whatever are their amplitudes have the greatest impact on human health.

The highest concentrations were observed in the dry season. Apart from the site of the E7 which is at the limit of the daily standard all other sampling sites exceed the WHO standard for $\mathrm{PM}_{2.5}$ by at least a coefficient of two. This may be explained by the fact that over this site there are many trees, which particles are deposited by impact. The high values observed at the RPNU can also be attributed to traffic congestion and heavy traffic at this site which is a road intersection where a long wait for vehicles was observed at the time of sampling and the difference in meteorology. Several studies in the literature found a significant relationship between emissions from high-traffic vehicles and air pollution concentrations (Akpan and William, 2014) (Gobo et al., 2012). According to Marticorena and coauthors (Marticorena et al., 2010), the minimum concentration of $\mathrm{PM}_{10}$ coincides with the maximum of rain falls which reduces dust emission by increasing soil moisture and the effect of scavenging.

The industrial activity of the region and even the country is mainly concentrated in the city of Ouagadougou. This explains the dynamics of the population of Burkina Faso towards the city of Ouagadougou. Also, the activity centers are concentrated in the city center and in a few peripheral districts, hence the massive daily movement of residents towards the activity areas. In addition, the 
Ouagadougou road network extends over a distance of 2700 kilometers with 200 $\mathrm{km}$ of paved roads, $400 \mathrm{~km}$ in laterite and $2100 \mathrm{~km}$ on the track (mixture of laterite, sand and clay), on which the traffic contributes by the suspension to the particles. All these parameters associated with an aging vehicle fleet explain the high concentrations PM recorded. The high values observed in rainy season can be attributed to winds that precede the rain by suspending important quantity of mineral dust.

Table 7 reports the PM concentrations of Sub-Saharan cities, from Bamako, Mali (Garrison et al., 2014), Accra, Ghana (Dotse et al., 2012), Dakar, Senegal (Demay, 2011) and Ouagadougou, Burkina Faso (Lindén et al., 2012) (Boman et al., 2009). PM concentrations vary between cities, even for those with similar climate and precipitation levels. It is well-known that PM emissions are strongly and negatively correlated with the Harmattan winds from the Sahara Desert and unpaved roads. As an illustration, Garrison and coauthors (Garrison et al., 2014) obtained for one day measurement, a 24-hour concentrations of 43 and 210 $\mu \mathrm{g} \cdot \mathrm{m}^{-3}$ for $\mathrm{PM}_{2.5}$ and $\mathrm{PM}_{10}$, respectively, in Bamako where the Harmattan winds are similar to those of Ouagadougou. Dotse and coauthors (Dotse et al., 2012) measured a 24-hour concentrations of 23.3 and $96.6 \mu \mathrm{g} \cdot \mathrm{m}^{-3}$ for $\mathrm{PM}_{2.5}$ and $\mathrm{PM}_{10}$, respectively, in Accra where the Harmattan winds are lower than those of Ouagadougou. $\mathrm{PM}_{2.5}$ pollution levels obtained in 2018 for the city of Ouagadougou $\left(57.9 \pm 10.5 \mu \mathrm{g} \cdot \mathrm{m}^{-3}\right)$ are close to those for Bamako $\left(43 \pm 21 \mu \mathrm{g} \cdot \mathrm{m}^{-3}\right)$. This seems

Table 7. Comparison of PM concentrations from sub-Saharan cities. Data in brackets correspond to the range of variation.

\begin{tabular}{|c|c|c|c|c|c|}
\hline \multirow[t]{2}{*}{ City, Country } & \multirow[t]{2}{*}{ Site type } & \multirow{2}{*}{$\begin{array}{l}\text { Measurements } \\
\text { Period }\end{array}$} & \multicolumn{2}{|c|}{$\begin{array}{l}\text { 24-hour concentrations } \\
\qquad\left(\mu \mathrm{g} \cdot \mathrm{m}^{-3}\right)\end{array}$} & \multirow[t]{2}{*}{ Ref. } \\
\hline & & & $\mathrm{PM}_{2.5}$ & $\mathrm{PM}_{10}$ & \\
\hline Bamako, Mali & Urban & $\begin{array}{l}12 / 09 / 2012- \\
09 / 07 / 2013\end{array}$ & $\begin{array}{c}43 \pm 21 \\
{[8-123]}\end{array}$ & $\begin{array}{c}210 \pm 93 \\
{[35-505]}\end{array}$ & $\begin{array}{l}\text { Garrison } \\
\text { et al., } 2014\end{array}$ \\
\hline Accra, Ghana & Urban & $14 / 02 /-23 / 05 / 2008$ & $\begin{array}{c}23.3 \\
{[3.9-46.4]}\end{array}$ & $\begin{array}{c}96.6 \\
{[37.1-193.1]}\end{array}$ & $\begin{array}{l}\text { Dotse et } \\
\text { al., } 2012\end{array}$ \\
\hline Dakar, Senegal & Urban & Jan-Dec 2010 & - & {$[59.3-388.0]$} & $\begin{array}{c}\text { Demay, } \\
2011\end{array}$ \\
\hline \multirow{5}{*}{$\begin{array}{l}\text { Ouagadougou, } \\
\text { Burkina Faso }\end{array}$} & $\begin{array}{l}\text { Urban } \\
\text { Suburban } \\
\text { Rural }\end{array}$ & 2007 & - & $\begin{array}{l}{[16.8-1010.1]} \\
{[10.0-2006.8]} \\
{[15.2-1177.7]}\end{array}$ & $\begin{array}{l}\text { Lindén et } \\
\text { al., } 2012\end{array}$ \\
\hline & $\begin{array}{c}\text { Urban } \\
\text { Suburban }\end{array}$ & $\begin{array}{l}29 \text { Nov. and } \\
11 \text { Dec. } 2007\end{array}$ & {$[27-164]$} & - & $\begin{array}{c}\text { Boman et } \\
\text { al., } 2009\end{array}$ \\
\hline & Urban & March-May 2018 & $87 \pm 16^{*}$ & $951 \pm 266^{*}$ & \multirow{3}{*}{$\begin{array}{l}\text { Present } \\
\text { study }\end{array}$} \\
\hline & Urban & July-August 2018 & $29 \pm 5^{*}$ & $158 \pm 43^{\star}$ & \\
\hline & Urban & June-September 2019 & $22 \pm 9$ & $187 \pm 64$ & \\
\hline
\end{tabular}

*These values correspond to 12 -hour concentration. 
logical in view of similar climates. However, it should be noted that the $\mathrm{PM}_{10}$ are more important in Ouagadougou and this is certainly linked to the traffic which is more important. These pollution levels are higher than recommended limits. These values are in the same order than those generally obtained on air pollution in West African cities. The reasons are also more or less identical, namely the high density of the population, the evolution of the vehicle fleet and the major part of the road network which is not subject to a limit.

\section{Conclusion}

PM monitoring campaigns were carried out in 2018 and 2019 in Ouagadougou, in order to investigate pollution levels and seasonal and spatial variability of these pollutants. It was found that no sites in Ouagadougou are exempt from PM pollution and this situation threatens comfort, human existence and the ecosystem, especially during the dry season. $\mathrm{PM}_{1}$ concentration values showed no significant variation between days, seasons and type of sampling sites, in opposite to $\mathrm{PM}_{2.5}$ or $\mathrm{PM}_{10}$ concentration values. These results are consistent with those of similar works in other African cities reported.

The concentration mean value of $\mathrm{PM}_{2.5}$ (respectively $\mathrm{PM}_{10}$ ) obtained during the 2019 rainy season is $22 \pm 9 \mu \mathrm{g} \cdot \mathrm{m}^{-3}$ (respectively $187 \pm 64 \mu \mathrm{g} \cdot \mathrm{m}^{-3}$ ). Concerning the $\mathrm{PM}_{2.5}$, the obtained value is relatively lower than the tolerable threshold value of $25 \mu \mathrm{g} \cdot \mathrm{m}^{-3}$ of the WHO recommendations, whereas this for $\mathrm{PM}_{10}$ is higher than the tolerable threshold value of $50 \mu \mathrm{g} \cdot \mathrm{m}^{-3}$ of the WHO recommendations. These high $\mathrm{PM}_{10}$ concentrations can be attributed to local dust (suspension linked to traffic and wind suspension of local dust), as shown in previous works. Modeling is a current perspective of traffic emission calculations and imputed traffic suspension on paved and unpaved roads. The dispersion of gaseous and particulate pollutants in the city of Ouagadougou are carried out using an urban model of dispersion of pollutants (MUNICH). This modeling will help to partially answer the following questions: what is the contribution of road traffic to $\mathrm{PM}_{2.5}$ exhaust emissions in the city? What is the contribution of road traffic to suspension of $\mathrm{PM}_{2.5}$ in the city? What is the contribution of road traffic to the resuspension of $\mathrm{PM}_{10}$ in the city? What are the predominant sources in modeling?

\section{Acknowledgements}

We are thankful to heads of different sites where measurement was done.

\section{Conflicts of Interest}

The authors declare no conflicts of interest regarding the publication of this paper.

\section{References}

Akpan, I. O., \& William, E. S. (2014). Assessment of Elemental Concentrations of Road- 
side Soils in Relation to Traffic Density in Calabar, Nigeria. International Journal of Scientific and Technology Research, 3, 3-10.

Amato, F. et al. (2016). Traffic Induced Particle Resuspension in Paris: Emission Factors and Source Contributions. Atmospheric Environment, 129, 114-124. https://doi.org/10.1016/j.atmosenv.2016.01.022

Beltrando, G. (2014). Pollution de l'air aux particules en suspension dans l'air (PM) et santé des individus: Un domaine de recherche pluridisciplinaire en développement pour les géographes. BSGLg, 62, 122-134.

Boman, J. et al. (2009). A Tentative Study of Urban and Suburban Fine Particles $\left(\mathrm{PM}_{2.5}\right)$ Collected in Ouagadougou, Burkina Faso. X-Ray Spectrometry, 38, 354-362. https://doi.org/10.1002/xrs.1173

Cassee, F. R. et al. (2013). Particulate Matter beyond Mass: Recent Health Evidence on the Role of Fractions, Chemical Constituents and Sources of Emission. Inhalation Toxicology, 25, 802-812. https://doi.org/10.3109/08958378.2013.850127

Chang, H. H., Peng, R. D., \& Dominici, F. (2011). Estimating the Acute Health Effects of Coarse Particulate Matter Accounting for Exposure Measurement Error. Biostatistics, 12, 637-652. https://doi.org/10.1093/biostatistics/kxr002

Chatoutsidou, S. E., \& Lazaridis, M. (2019). Assessment of the Impact of Particulate Dry Deposition on Soiling of Indoor Cultural Heritage Objects Found in Churches and Museums/Libraries. Journal of Cultural Heritage, 39, 221-228. https://doi.org/10.1016/j.culher.2019.02.017

Chen, S. et al. (2019). Fugitive Road Dust $\mathrm{PM}_{2.5}$ Emissions and Their Potential Health Impacts. Environmental Science and Technology, 53, 8455-8465. https://doi.org/10.1021/acs.est.9b00666

De Longueville, F. et al. (2010). What Do We Know about Effects of Desert Dust on Air Quality and Human Health in West Africa Compared to Other Regions? Science of the Total Environment, 409, 1-8. https://doi.org/10.1016/j.scitotenv.2010.09.025

Demay, C. (2011). La pollution de l'air à Dakar (p. 28). Agence de l'environnement et de la maitrise de l'énergie. http://climatologie.u-bourgogne.fr/documents/theses_master/2011/Demay_2011.pdf

DMN (201AD). Burkina Faso Direction de la Météorologie Nationale. (Ouagadougou, 2001)

Dotse, S. et al. (2012). Particulate Matter and Black Carbon Concentration Levels in Ashaiman, a Semi-Urban Area of Ghana, 2008. Research Journal of Environmental and Earth Sciences, 4, 20-25.

Duan, J. et al. (2015). Characteristics and Relationship of $\mathrm{PM}, \mathrm{PM}_{10}, \mathrm{PM}_{2.5}$ Concentration in a Polluted City in Northern China. Procedia Engineering, 102, 1150-1155. https://doi.org/10.1016/j.proeng.2015.01.239

Eliasson, I., Jonsson, P., \& Holmer, B. (2009). Diurnal and Intra-Urban Particle Concentrations in Relation to Windspeed and Stability during the Dry Season in Three African Cities. Environmental Monitoring and Assessment, 154, 309-324. https://doi.org/10.1007/s10661-008-0399-y

Etyemezian, V. et al. (2005). Results from a Pilot-Scale Air Quality Study in Addis Ababa, Ethiopia Results from a Pilot-Scale Air Quality Study in Addis Ababa, Ethiopia. https://doi.org/10.1016/j.atmosenv.2005.08.033

Garrison, V. H. et al. (2014). Inhalable Desert Dust, Urban Emissions, and Potentially Biotoxic Metals in Urban Saharan-Sahelian Air. Science of the Total Environment, 500-501, 383-394. https://doi.org/10.1016/j.scitotenv.2014.08.106 
Gobo, A. et al. (2012). Assessment of Air Quality and Noise around Okrika Communities, Rivers State. Journal of Applied Sciences and Environmental Management, 16, 75-83.

Goudie, A. S., \& Middleton, N. J. (2001). Saharan Dust Storms: Nature and Consequences. Earth-Science Reviews, 56, 179-204. https://doi.org/10.1016/S0012-8252(01)00067-8

Janae, C. et al. (2014). Effect of Wind Speed and Relative Humidity on Atmospheric Dust Concentrations in Semi-Arid Climates. Science of the Total Environment, 487, 82-90. https://doi.org/10.1016/j.scitotenv.2014.03.138

Kliengchuay, W. et al. (2018). Relationships between Meteorological Parameters and Particulate Matter in Mae Hong Son. International Journal of Environmental Research and Public Health, 15, 2801. https://doi.org/10.3390/ijerph15122801

Lee, J. et al. (2019). Ceilometer Monitoring of Boundary-Layer Height and Its Application in Evaluating the Dilution Effect on Air Pollution. Boundary-Layer Meteorology, 172, 435-455. https://doi.org/10.1007/s10546-019-00452-5

Li, T. et al. (2018). All-Cause Mortality Risk Associated with Long-Term Exposure to Ambient PM 2.5 in China: A Cohort Study. The Lancet Public Health, 3, e470-e477. https://doi.org/10.1016/S2468-2667(18)30144-0

Lindén, J. et al. (2012). Intra-Urban Air Pollution in a Rapidly Growing Sahelian City. Environment International, 40, 51-62. https://doi.org/10.1016/j.envint.2011.11.005

Lindén, J., \& Holmer, B. (2011). Thermally Induced Wind Patterns in the Sahelian City of Ouagadougou, Burkina Faso. Theoretical and Applied Climatology, 105, 229-241. https://doi.org/10.1007/s00704-010-0383-7

Lindén, J., Thorsson, S., \& Boman, J. (2012). Urban Climate and Air Pollution in Ouagadougou, Burkina Faso-A Review of Results from Five Field Studies (pp. 1-17).

Louati, A., Son, L. H., \& Chabchoub, H. (2018). SGA: Spatial GIS-Based Genetic Algorithm for Route Optimization of Municipal Solid Waste Collection. Environmental Science and Pollution Research, 25, 27569-27582. https://doi.org/10.1007/s11356-018-2826-0

Marticorena, B. et al. (2010). Temporal Variability of Mineral Dust Concentrations over West Africa: Analyses of a Pluriannual Monitoring from the AMMA Sahelian Dust Transect. Atmospheric Chemistry and Physics, 10, 8899-8915. https://doi.org/10.5194/acp-10-8899-2010

Nana, B. et al. (2012). Air Quality Study in Urban Centers: Case Study of Ouagadougou, Burkina Faso. FUTY Journal of the Environment, 7, 1-18. https://doi.org/10.4314/fje.v7i1.1

Petäjä, T. et al. (2016). Enhanced Air Pollution via Aerosol-Boundary Layer Feedback in China. Scientific Reports, 6, Article No. 18998. https://doi.org/10.1038/srep18998

Petkova, E. P. et al. (2013). Particulate Matter Pollution in African Cities. Air Quality, Atmosphere and Health, 6, 603-614. https://doi.org/10.1007/s11869-013-0199-6

Prasad, G. (2011). Improving Access to Energy in Sub-Saharan Africa. Current Opinion in Environmental Sustainability, 3, 248-253. https://doi.org/10.1016/j.cosust.2011.05.003

Presidence du Faso (2001). Décret n02001-185/PRES/WMMEE portant fixation des normes de rejel de polluants dans l'air, l'eau et le sol. http://extwprlegs1.fao.org/docs/pdf/bkf26794.pdf

Radaideh, J. A. (2017). Environmental \& Analytical Toxicology Effect of Meteorological Variables on Air Pollutants Variation in Arid Climates. Journal of Environmental \& Analytical Toxicology, 7, 478. https://doi.org/10.4172/2161-0525.1000478

Sarr, D. et al. (2018). Atmospheric Circulation in Low Troposphere-Effect on $\mathrm{NO}_{x}$ and CO Emissions in Traffic and Air Quality in Dakar. Journal of Pollution Effects \& Con- 
trol, 6, 230. https://doi.org/10.4172/2375-4397.1000230

Somda, D. D. (2018). Inventaire d'émissions de polluants atmosphériques issus du trafic routier à Ouagadougou (Burkina Faso).

Son, L. H., \& Louati, A. (2016). Modeling Municipal Solid Waste Collection: A Generalized Vehicle Routing Model with Multiple Transfer Stations, Gather Sites and Inhomogeneous Vehicles in Time Windows. Waste Management, 52, 34-49. https://doi.org/10.1016/j.wasman.2016.03.041

Talbi, A., Kerchich, Y., \& Kerbachi, R. (2017). Assessment of Annual Air Pollution Levels with $\mathrm{PM}_{1}, \mathrm{PM}_{2.5}, \mathrm{PM}_{10}$ and Associated Heavy Metals in Algiers, Algeria. Environmental Pollution, 232, 252-263. https://doi.org/10.1016/j.envpol.2017.09.041

Titcombe, M. E., \& Simcik, M. (2011). Personal and Indoor Exposure to $\mathrm{PM}_{2.5}$ and Polycyclic Aromatic Hydrocarbons in the Southern Highlands of Tanzania: A Pilot-Scale Study. Environmental Monitoring and Assessment, 180, 461-476. https://doi.org/10.1007/s10661-010-1799-3

Tsai, M. Y. et al. (2015). Spatial Variation of PM Elemental Composition between and within 20 European Study Areas-Results of the ESCAPE Project. Environment International, 84, 181-192. https://doi.org/10.1016/j.envint.2015.04.015

UN-HABITAT (2010). State of African Cities 2010, Governance, Inequality and Urban Land Markets. Nairobi: UNON/Publishing Services Section/Nairobi. 